\title{
Embryonic and host-associated skewed adult sex ratios in dwarf mistletoe
}

\author{
DELBERT WIENS, DANIEL L. NICKRENT*†, CHARLES G. SHAW III $\ddagger$ FRANK G. \\ HAWKSWORTH§ף, PAUL E. HENNON $\$$ \& EDWARD J. KING \\ Department of Biology, University of Utah, Salt Lake City, UT 84112 and White Mountain Research Station, $3000 \mathrm{E}$. \\ Line Street, Bishop, CA 93514, †Department of Plant Biology, Southern Illinois University at Carbondale, \\ Carbondale, IL 62901, $\ddagger$ Pacific Northwest Forest and Range Experiment Station, Forestry Sciences Laboratory, 2770 \\ Sherwood Lane, Juneau, AK 99801 and §Rocky Mountain Forest and Range Experiment Station, 240 W. Prospect \\ Road, Fort Collins, CO 80526, U.S.A.
}

\begin{abstract}
Embryonic sex ratios were determined for the first time in dioecious flowering plants by utilizing malate dehydrogenase $(M d h-3)$ as a genetic marker. In three populations of Arceuthobium tsugense ssp. tsugense (hemlock dwarf mistletoe) the embryonic sex ratio was $1: 1$, as it also was at first reproduction. Mixed-age, adult sex ratios of these and other populations from Oregon to south-eastern Alaska, however, were significantly female-biased (59 per cent) on western hemlock, its primary host. We suggest that these female-skewed, adult sex ratios are the result of increased longevity among females. On a secondary host, noble fir, the embryonic and the adult sex ratios were both $1: 1$. On still another secondary host, shore pine, the embryonic sex ratio is unknown, but the adult sex ratio was significantly male-biased (55.1 per cent). Host environment apparently influences adult sex ratios in hemlock dwarf mistletoe. However, in the European mistletoe Viscum album, a gametic system apparently controls the production of the adult female-predominant sex ratios (69.9 per cent) at fertilization (or perhaps by abortion during embryogenesis). In $V$. album, the sex ratio of progeny raised from seed is already similarly biased at first reproduction ( 67.3 per cent), and the sex ratios are not influenced by host shifts.
\end{abstract}

Keywords: dwarf mistletoes, flowering plants, sex ratios, Viscum.

\section{Introduction}

Flowering plants are predominately hermaphrodites, but dioecy occurs in about 3-4 per cent of the species in the north temperate floras, including the British Isles (Kay \& Stevens, 1986). Dioecy in flowering plants also typically shows low genetic penetrance and many species are only facultatively dioecious because they often produce low proportions of flowers with variable sexual expression ('leaky dioecy'; Baker \& Cox, 1984). However, in contrast to such facultative, labile sexual expression, all 42 species of dwarf mistletoe (Arceuthobium, Viscaceae) are obligately dioecious (Hawksworth \& Wiens, 1972, 1996). Their flowers are strongly dimorphic and bear no vestigial structural elements of the opposite sex. Sexual dimorphism also charac-

*Correspondence.

IDeceased. terizes whole plant morphology in the majority of dwarf mistletoes. Unlike dioecy in most plants, high genetic penetrance is exhibited by all dioecious mistletoes, including the European mistletoe, Viscum album L., and other species of Viscum where sex determination is associated with chromosomal translocation complexes in male plants (Wiens \& Barlow, 1973, 1975, 1979; Barlow \& Wiens, 1976; Mechelke, 1976; Barlow et al., 1978; Barlow, 1981; Aparicio, 1993, 1995). Sex chromosomes are suspected, but not demonstrated, in several species of dwarf mistletoe (Wiens, 1968). Although biased adult sex ratios in flowering plants are most commonly male-skewed (Lloyd, 1974; Willson, 1983), female-predominant adult sex ratios are generally the rule among dioecious mistletoes (Barlow et al., 1978; Wiens \& Barlow, 1979; Nixon \& Todzia, 1985; Aparicio, 1993), although one malebiased sex ratio has been reported (Dawson et al., 1990). 
Sex ratio distortions in plants are often influenced by the environment (Freeman et al., 1976). The patchiness, and especially the difficulty in defining precise habitats in complex terrestrial communities, however, make it difficult to correlate specific habitats with a particular sex ratio bias. This problem is eliminated in aerial parasites because the habitat (host) can be clearly identified (Dawson et al., 1990). Most dioecious mistletoes, including dwarf mistletoes, parasitize a variety of hosts, thus providing a number of diverse, specific habitats that can be analysed for variation in sex ratios.

The absence of sex ratio data for zygotes, embryos, and nonreproductive individuals has impeded the study of sex ratios in plants. Hemlock dwarf mistletoe Arceuthobium tsugense (Rosendahl) G. N. Jones ssp. tsugense is a virulent and economically important pathogen of western hemlock Tsuga heterophylla Sarg. in the Pacific north-west of North America (Smith, 1969; Shaw, 1982; Shaw \& Hennon, 1991). Previous studies of enzyme polymorphism among host races of $A$. tsugense showed a strong correlation between genotypes of malate dehydrogenase $(M d h-3)$ and the sex of the adult dwarf mistletoe plant (Nickrent \& Butler, 1990; Nickrent \& Stell, 1990). Modification of the electrophoretic techniques to analyse the seeds of dwarf mistletoes permitted the use of $M d h-3$ as a genetic marker to determine the sex of the embryos (Nickrent, 1986, unpublished data). To our knowledge this is the first report of embryonic sex ratio determination in plants, although the sexes of juvenile plants of Viscum album were identified by the presence or absence of two $17 \mathrm{kDa}$ proteins (Schink \& Mechelke, 1989). Correlations between the sex of adult plants and electrophoretic markers have also been observed in the honey locust (Schnabel \& Hamrick, 1990), plantain (Wulff, 1987), dates (Suganuma \& Iwasaki, 1983) and papaya (Minoz et al., 1982). Mulcahy et al. (1992) developed a DNA probe to identify plants of Silene latifolia possessing the $\mathrm{Y}$ chromosome. However, in none of these studies was the technique applied to embryos, nor were the sex ratios of these species necessarily distorted at any stage of the life cycle.

In this study, embryonic sex ratios (1:1) in hemlock dwarf mistletoes are compared with the sex ratios of young plants at first reproduction, and with those of adult populations, which differ significantly according to the host species. This apparent environmental (host) influence on the adult sex ratio in dwarf mistletoes is contrasted to the situation in Viscum where sex ratios are likely to be under genetic control involving a gametic selection system.

\section{Materials and methods}

Adult male hemlock dwarf mistletoe plants are heterozygous for $M d h-3$ and possess an $A C$ genotype, whereas female plants are homozygous and exhibit $A A$ genotypes (Fig. 1a) (Nickrent \& Butler, 1990; Nickrent \& Stell, 1990). This suggests close genetic linkage between the $M d h-3$ locus and the sex-determining gene(s) (Fig. 1). The linkage is not complete, however, because a low proportion of recombinant genotypes occurs in the adult plants (Table 1). These loci could be in linkage disequilibrium. There is no obvious reason, however, to suspect that linkage between $M d h-3$ and sex determination should be favoured by natural selection, as

Fig. 1 Gel zymograms of Arceuthobium tsugense ssp. tsugense stained for malate dehydrogenase, present as at least four anodal loci. Interlocus heterodimeric enzymes (IL) are indicated between loci 2 and 3. Plant sex is associated with electrophoretic phenotypes observed at locus 3. (a) Electrophoretic phenotypes for 10 adult individuals from the Mary's Peak, OR population. Lanes $1-5$ are from male plants that show $A C$ genotypes, whereas lanes 6-10 are from female plants that show $A A$ genotypes. (b) Electrophoretic phenotypes for five seeds from the Mary's Peak population. Individuals 1 and 5 have the $A A A$ (female) genotype, 2-4 have the $A A C$ (male) genotype.
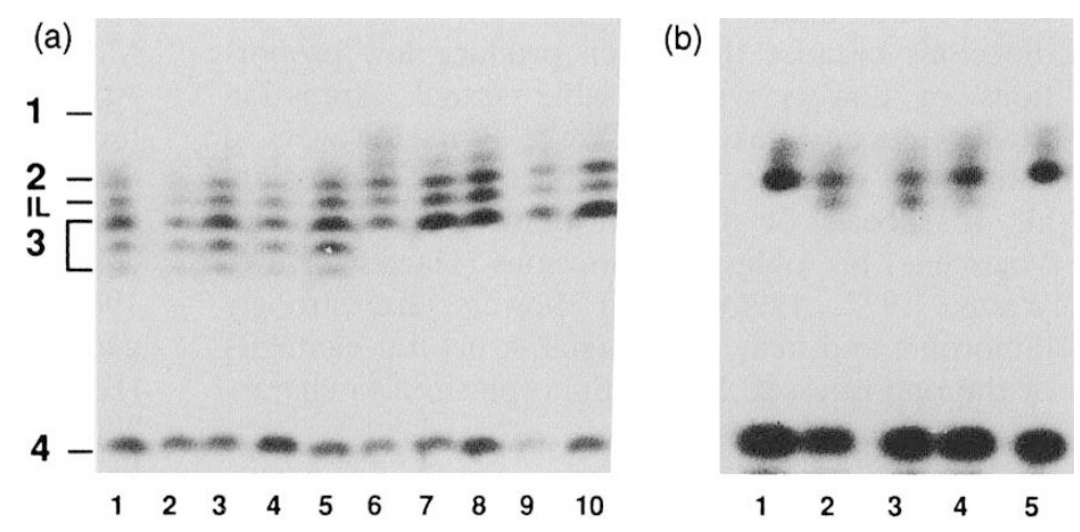

(c) The Genetical Society of Great Britain, Heredity, 77, 55-63. 


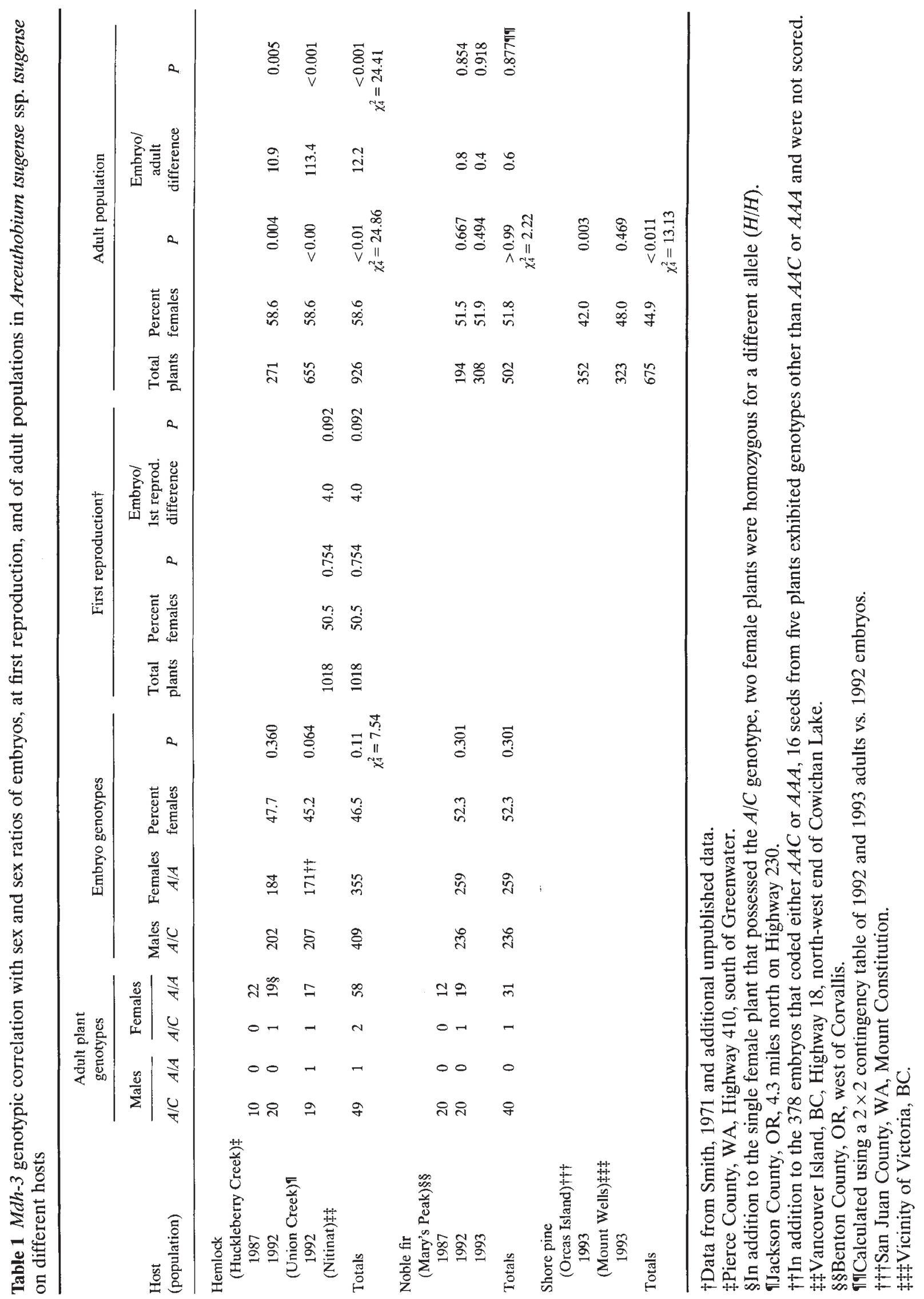

(C) The Genetical Society of Great Britain, Heredity, 77, 55-63. 
are for example the supergenes that control heterostyly in Primula (Ford, 1971), and which also produce a similarly low proportion of recombinant genotypes.

Germinating seeds consisting only of embryos $(2 n)$ and endosperm $(3 n)$ were utilized in the electrophoretic analyses to determine the sex of the embryos (Nickrent, 1986). The seeds of dwarf mistletoes possess no seed coat, and when other structures (primarily viscin) are removed, there is no remaining tissue of maternal origin that might complicate the analysis. The embryo/endosperm genotypes will therefore code $A C / A A C$ for males and $A A / A A A$ for females (Fig. 1b).

Samples for determining adult sex ratios in Table 1 were taken from populations comprised primarily of young plants with vigorous shoot production that often parasitized relatively young host trees. Such infections are typically $7-15$ years old, and exhibit little, if any, distortion of the host branching patterns (witches' brooms) that are symptomatic of older infections. Many of the samples in Table 2, however, were obtained from populations consisting mostly of older infections exhibiting extensive witches' broom formation. Dwarf mistletoe shoot production was not only uncommon in such old infections, but if present, the shoots were also often nonreproductive. This accounts for the small sample sizes sometimes obtained in these populations (Table 2). No attempt was made, however, to limit sampling to either young or old infections and most samples were mixed to some extent so that the age ratings in Table 2 are only tentative. Practical considerations required that samples were taken from branches mostly (but not exclusively) within $4 \mathrm{~m}$ of the ground.

Independent probabilities determined by $\chi^{2}$ tests were combined to obtain tests of overall significance in Tables 1 and 2 (Steel \& Torrie, 1980). Other probability values of $\chi^{2}$ tests, cited only in the text or in Tables 3 and 4 , were calculated individually using $2 \times 2$ contingency tables. A sign test was utilized to determine the significance of the proportion of populations that exhibited excess females in Tables 2 and 3 .

\section{Results}

The embryonic sex ratios were determined for three populations of $A$. tsugense (Table 1). Two of these geographically diverse populations parasitized the typical host, western hemlock, and the embryos exhibited the 1:1 sex ratio expected at fertilization (Fisher, 1958). The adult plants in both of the popu-
Table 2 Sex ratios in adult populations of Arceuthobium tsugense ssp. tsugense parasitic on Tsuga heterophylla

\begin{tabular}{|c|c|c|c|}
\hline Population & $\begin{array}{l}\text { Total } \\
\text { plants }\end{array}$ & $\begin{array}{c}\text { Sex ratio } \dagger \\
\text { (\% females) }\end{array}$ & $P$ \\
\hline Haines AK $\ddagger$ & 74 & 60.8 & 0.063 \\
\hline Juneau AK‡ & 94 & 59.6 & 0.063 \\
\hline Sitka AK $\ddagger$ & 15 & 60.0 & 0.439 \\
\hline Ketchikan AK $\ddagger$ & 70 & 70.0 & 0.001 \\
\hline Nitinat $\mathrm{BC} \ddagger$ & 64 & 59.4 & 0.134 \\
\hline Lake Cowichan BC & 257 & 52.1 & 0.493 \\
\hline Mount Baker WA $\ddagger$ & 22 & 63.6 & 0.201 \\
\hline Port Angeles WA & 34 & 73.5 & 0.006 \\
\hline Snoqualmie Pass WA & 29 & 58.6 & 0.353 \\
\hline Whidbey Island WA & 405 & 56.3 & 0.011 \\
\hline Huckleberry Creek WA & 271 & 58.7 & 0.004 \\
\hline Nemah WA $\ddagger$ & 59 & 45.7 & 0.515 \\
\hline White Pass WA & 238 & 59.7 & 0.003 \\
\hline Poop Creek OR & 733 & 61.5 & $<0.001$ \\
\hline Rebel Creek OR & 37 & 70.3 & 0.014 \\
\hline Union Creek OR & 655 & 58.6 & $<0.001$ \\
\hline Total/Mean & 3057 & 59.0 & $\begin{aligned} & <0.001 \\
\chi_{32}^{2}= & 116.65\end{aligned}$ \\
\hline
\end{tabular}

$\dagger$ A sign test showed that the number of populations showing excess females was highly significant $(P=0.0004)$. † Samples originating primarily from old infections; all others generally from young infections.

lations from which the embryonic sex ratios were determined, as well as of 14 other populations from south-eastern Alaska to southern Oregon, show significantly female-skewed sex ratios approaching 2:3 (Tables 1 and 2). The third population of $A$. tsugense for which an embryonic sex ratio was obtained infected a secondary host, the noble fir Abies procera Rehd., but on this host both the embryonic and adult sex ratios were $\approx 1: 1$ (Table 1 ). Finally, a male-biased adult sex ratio occurred on still another secondary host, the shore pine Pinus contorta Dougl. ssp. contorta, when the data were pooled (Table 1). Unfortunately, the embryonic sex ratio for $A$. tsugense parasitizing shore pine has not been analysed.

Gender is also correlated with the genotypes of the $M d h-3$ locus in $A$. tsugense ssp. mertensianae Hawksworth \& Nickrent, and $A$. littorum Hawksworth, Wiens \& Nickrent (Nickrent \& Butler, 1990). The former parasitizes the mountain hemlock Tsuga mertensiana (Bong.) Carriàre, but also occurs secondarily on the subalpine fir Abies lasiocarpa (Hook.) Nutt., noble fir $A$. procera Rehd., silver fir A. amabilis (Douglas) James Forbes, western white pine $P$. monticola Douglas, and whitebark pine $P$. 
Table 3 Summary of adult sex ratios obtained from different species of Arceuthobium (data ours unless otherwise indicated)

\begin{tabular}{|c|c|c|c|c|c|}
\hline Species & Location & Host & $\begin{array}{l}\text { Total } \\
\text { plants }\end{array}$ & $\begin{array}{c}\text { Sex ratio } \\
(\% \text { female }) \dagger\end{array}$ & $P$ \\
\hline A. americanum $\ddagger$ & Alta (Can.) & Pinus contorta & 1230 & 51.0 & NS \\
\hline A. americanum & $\mathrm{CO}$ & $P$. contorta & 500 & 51.0 & NS \\
\hline A. apachecum & $\mathrm{AZ}$ & P. strobiformis & 457 & 58.6 & $<0.001$ \\
\hline A. campylopodum & $\mathrm{CA}$ & P. ponderosa & 345 & 54.5 & NS \\
\hline A. campylopodum§ & WA & P. ponderosa & 100 & 53.0 & NS \\
\hline A. divaricatum & NV & P. monophylla & 210 & 46.2 & NS \\
\hline A. gillii & $\mathrm{AZ}$ & P. chihuahuana & 293 & 56.7 & $<0.025$ \\
\hline \multirow[t]{2}{*}{ A. globosum } & \multirow[t]{2}{*}{ DGO (Mex.) } & P. cooperi & 130 & 55.4 & NS \\
\hline & & P. durangensis & 142 & 64.1 & $<0.001$ \\
\hline A. hawksworthii & Belize & P. caribaea & 50 & 62.0 & NS \\
\hline A. laricis $\mathbb{1}$ & WA & Larix occidentalis & 1651 & 51.2 & NS \\
\hline A. littorum & $\mathrm{CA}$ & P. radiata & 365 & 46.0 & NS \\
\hline A. occidentale & $\mathrm{CA}$ & P. sabiniana & 426 & 46.5 & NS \\
\hline A. strictum & DGO (Mex.) & P. leiophylla & 79 & 59.5 & NS \\
\hline A. vaginatum & & & & & \\
\hline ssp. cryptopodum $\dagger^{\dagger}$ & $\mathrm{AZ}$ & P. ponderosa & 1000 & 51.0 & NS \\
\hline
\end{tabular}

NS $=$ not significantly different $(P>0.05)$.

$\uparrow$ A sign test showed that the number of species showing excess females was significant $(P=0.03)$.

¥Muir, 1968.

§Wicker, 1967.

IR. L. Mathiasen, unpublished data.

††Hawksworth, 1961.

Table 4 Sex ratios at first reproduction in Arceuthobium progeny derived from seeds (data ours unless otherwise indicated)

\begin{tabular}{lllrcr}
\hline Species & Location & Host & $\begin{array}{c}\text { Total } \\
\text { plants }\end{array}$ & $\begin{array}{c}\text { Sex ratio } \\
\text { (\% female) }\end{array}$ & $P$ \\
\hline A. abietinum $\dagger$ & CA & Abies magnifica & 117 & 52.9 & NS \\
A. abietinum $\dagger$ & CA & Abies concolor & 117 & 43.6 & NS \\
A. americanum & CO & Pinus contorta & 475 & 53.1 & NS \\
A. pusillum $\ddagger$ & MN & Picea mariana & 51 & 62.7 & NS \\
A. tsugense $\$$ & BC & Tsuga heterophylla & 1018 & 50.5 & NS \\
\hline
\end{tabular}

NS $=$ not significantly different $(P>0.05)$.

$\nmid$ Scharpf \& Parmeter, 1982.

¥Baker et al., 1981.

$\S$ Smith, 1971 and additional unpublished data. The data for $A$. tsugense were obtained from marked, spontaneously dispersed seeds. All others were derived from hand inoculations.

albicaulis Engelm. (Hawksworth \& Wiens, 1996). Two populations of $A$. tsugense ssp. mertensianae also showed significantly female-biased adult sex ratios of about 2:3 in Douglas County, OR, when parasitizing mountain hemlock (Diamond Lake, 139 plants, 61.9 per cent females, $P<0.001$ ) and when infesting a mixed stand of mountain hemlock and subalpine fir (Windigo Pass, 106 plants, 63.2 per cent females, $P<0.01)$. The adult sex ratio of $A$. littorum on the Monterey pine $P$. radiata Don is $1: 1$ 
(Cambria, CA, 365 plants, 46.0 per cent females, $P>0.1$ ). This dwarf mistletoe has a restricted distribution along the central California coast where it also infects the bishop pine $P$. muricata Don. Preliminary determinations of adult sex ratios have also been obtained for other species of dwarf mistletoe (Table 3). The sample sizes were often small; however, the number of species exhibiting excess females (12 out of 15) was significant $(P=0.03)$.

Wherever adult sex ratios of $A$. tsugense on western hemlock differ significantly from 1:1, they are always female-biased in proportions approaching $2: 3$, regardless of geographical distribution or whether the populations were comprised primarily of younger or older individuals (Table 2). When the sample size was increased by pooling the data, the ratios remained at $\approx 2: 3$ and were overall highly significant $(P<0.001)$ as was the number of populations (15 out of 16) that showed an excess of females $(P=0.0004)$. Failure of multi-aged adult populations of $A$. tsugense to exhibit significantly female-biased sex ratios was associated with either a shift from the typical host (western hemlock) to a secondary host, i.e. noble fir or shore pine, or with relatively small sample sizes.

\section{Discussion}

The ability to identify the sexual genotype of mature embryos and other minute quantities of tissue provides a new means of studying sex ratios in plants. In dwarf mistletoes, and dioecious species in general, populations typically contain varying numbers of nonreproductive individuals, e.g. juvenile plants may comprise 10-20 per cent of young populations of $A$. tsugense, and thus constitute a major source of uncertainty in determining sex ratios. In addition, populations of hemlock dwarf mistletoe, especially in Alaska, are often characterized by the presence of numerous older individuals that rarely produce shoots (Table 2). The gender of such old, shootless infections might nonetheless be determined electrophoretically from small samples of tissue isolated from the endophytic system.

Sex ratios could be skewed at the time of fertilization (gametic selection), by sex-differential embryo mortality, or meiotic drive (the latter two unknown in plants). Environmental factors and inherent physiological differences between the sexes may also distort sex ratios with increasing age. In $A$. tsugense there is an embryonic abortion rate of $\approx 40$ per cent (Wiens, Shaw, Hawksworth \& Hennon, unpublished data) which is typical of herbaceous outcrossing plants in general (Wiens, 1984: Wiens et al., 1987).
The embryonic sex ratio of 1:1 at dispersal, however, precludes the occurrence of significant sex-differential embryo abortion (Table 1). The viability of dwarf mistletoe seeds is high and germination in $A$. tsugense regularly exceeds 90 per cent (Nickrent, 1986, unpublished data). Thus sex-differential seed mortality or germinability likewise cannot explain the female-biased adult sex ratios. Furthermore, long-term studies of infection and seedling development in $A$. tsugense and other species also show that at first reproduction the sex ratio is still 1:1 (Smith, 1971; Table 4). Thus, whatever factors control the sex ratios in adult populations of $A$. tsugense, they apparently operate only after the plants attain sexual maturity.

A number of testable, environmentally related hypotheses might explain the higher proportion of female plants observed in mixed-age, adult populations of $A$. tsugense on western hemlock. These include sex-differential responses to (i) predation, (ii) pathogens, (iii) resource-limited stress and (iv) site preferences on the host (niche partitioning). Other explanations that are also testable include (v) sex-switching, (vi) 'lazy males' (i.e. old infections that rarely produce shoots might be comprised largely of male plants) and (vii) greater longevity of female plants (and concomitant increased male attrition).

The parasites and predators of dwarf mistletoes have been the subject of intensive field research because of the latters' prominence as forest pathogens. There is no evidence, however, for sex-differential behaviour among these organisms, which are predominantly fungi and insects (Hawksworth \& Wiens, 1996). Dwarf mistletoes are well known to constitute resource sinks (Lamont, 1983); thus resource-limited stress appears unlikely to contribute significantly to mortality in either sex. Among mistletoes, niche partitioning between the sexes has been noted only in the related genus Phoradendron (Dawson et al., 1990), although it is common in terrestrial plants (Cox, 1981). The extensive field studies that have been conducted on dwarf mistletoes have revealed no evidence for the occurrence of niche partitioning (Hawksworth \& Wiens, 1996). Sex-switching is, to our knowledge, unknown in obligately dioecious plants that display sexual dimorphism. Furthermore, in $A$. tsugense the sex of marked shoots did not vary for periods of up to 7 years (Smith, 1971). The occurrence of similar femalebiased sex ratios $(\approx 2: 3)$ in populations comprised either of mostly young infections (without extensive witches' broom formation) or old infections where shoot formation was rare, argues against the 'lazy 
male' hypothesis. The 'lazy male' hypothesis is also testable by determining the gender of such old infections electrophoretically.

We infer that the female-biased adult sex ratios observed in $A$. tsugense are most likely the result of greater longevity of the female plants. This in turn suggests possible inherent physiological differences between the sexes, as has been demonstrated in willows and boxelder (Crawford \& Balfour, 1983; Dawson \& Bliss, 1989; Dawson \& Ehleringer, 1993). Such a sex-differential longevity hypothesis is also falsifiable as infections can be aged in $A$. tsugense (Smith, 1971; Shaw, 1982) and other dwarf mistletoes because the growth rings of the host branch become distorted at the time of infection (Scharpf \& Parmeter, 1966). If female plants possess greater longevity than males, then the sex ratios of adult populations should be directly correlated with their age structure, i.e. cohorts of increasingly older individuals should be represented by a proportionately larger number of females, as occurs in willows (Falinski, 1980; Alliende \& Harper, 1989) and also in human beings (Cavalli-Sforza \& Bodmer, 1971).

In contrast to Arceuthobium, a gametic selection system may operate in Viscum whereby gametes of one sex are regularly favoured at fertilization (Correns, 1928). Such systems are apparently uncommon, presumably because the gametes differ genetically owing to the presence of sex chromosomes which are rare in flowering plants (Westergaard, 1958; Grant, 1975; Meagher, 1988). In dioecious Viscum the male- and female-determining pollen grains are produced in equal numbers (thus precluding meiotic drive) and, as previously mentioned, differ genetically by the presence of reciprocal chromosome translocation complexes in the male gametes. In $V$. fischeri Engl., the gametes also differ in the actual number of chromosomes (Wiens \& Barlow, 1973, 1975; Barlow \& Wiens, 1976). Furthermore, the sex ratio of plants of $V$. album raised from seed (Showler, 1974) was already highly female-skewed at first reproduction [107 plants, 67.3 per cent females, $P<0.001\left(\chi^{2}\right.$ test is ours)] and closely approximates the female-biased sex ratio (69.9 per cent) of the multi-aged adult populations occurring in England (Barlow et al., 1978), where Showler's experiment was conducted.

There is also no correlation between host and the sex ratio in $V$. album. Populations of this mistletoe naturalized in California, on hosts not present in England, exhibit sex ratios (67.3 per cent females) remarkably similar to those in England (69.9 per cent females) (Barlow et al., 1978). The naturalized population of $V$. album in California probably also developed from seed originating in England (Hawksworth \& Scharpf, 1987). Unfortunately, the embryonic sex ratio in Viscum is unknown and neither the Mdh-3 locus nor 19 other loci analysed in $V$. album are linked to the sex-determining gene(s): (Aat-1, -2 , -3; Aco; Adh-1; Gdh; G6pdh; Idh-2; Mdh-2; Mdr; Me-1, -2; 6-Pgd; Pgi-2; Pgm-1, -2; Tpi -1, -2, -3). The sex-specific protein identified by Schink \& Mechelke (1989) in juvenile $V$. album, however, might also be utilized for determining the sex of the embryos. The adult sex ratios in Viscum (i) exhibit a female bias greater than that observed in Arceuthobium (1:2 vs. $2: 3$ ), (ii) are female-skewed at first reproduction and (iii) are unaffected by host.

The consistency of the female bias in adult sex ratios of around 2:3 in $A$. tsugense on western hemlock (Table 2), contrasts with the variability in the female-predominant sex ratios observed in terrestrial genera where ambient environment apparently controls adult sex ratios. In Rumex, the sex ratio of progeny grown from seed is $1: 1$ at first reproduction; however, the female-biased adult sex ratios vary widely in natural populations $(52-93$ per cent) (Zarzycki \& Rychlewski, 1972). This is probably attributable to the greater patchiness that typifies terrestrial habitats, as opposed to the relative uniformity and clear identification of the host environments that characterize mistletoes.

Mistletoes (Viscaceae) are excellent organisms in which to study sex ratios in flowering plants. Both environmental and genetic control mechanisms are apparently operative and the genetic penetrance of dioecy is virtually complete. In Arceuthobium, where the system is environmentally controlled, the sexual genotypes of embryos, other tissue, and nonreproductive individuals can be identified. The habitat (host) shifts that influence sex ratio changes are thus clearly demarcated, and also variable, because most dwarf mistletoes typically develop large populations on a number of secondary hosts. In Viscum, sex ratio bias is apparently controlled by genetic factors operating at the gametic (or embryonic?) level and in some species chromosome markers are available to determine sex (Wiens \& Barlow, 1974). Problems relating to the parasitic habit and long generation time can be largely overcome by growing the mistletoes on young host plants under glasshouse conditions. Some dwarf mistletoes reach sexual maturity in 6-12 months under such conditions, as opposed to 5-7 years in nature (Hawksworth \& Wiens, 1996). The long period of fruit maturation in many temperate dwarf mistletoes (12-18 months) can probably also be decreased under greenhouse conditions, or avoided by utilizing tropical species, e.g. $A$. hawks- 
worthii, in which fruiting requires perhaps 4-6 months (Wiens \& Shaw, 1994).

\section{Acknowledgements}

We thank A. Daley, G. Filipe, K. Marshall, M. Murray, R. B. Smith, G. Thackray, L. Trumer, E. Wass, A. Wiens and especially M. McWilliams for field assistance, and B. Beilschmidt for laboratory assistance. We are indebted to R. King for statistical assistance with Tables 1 and 2. The Rocky Mountain Forest and Range Experiment Station, Fort Collins, CO, provided financial support. L. Allphin, C. L. Calvin, E. R. Charnov, P. Cox, D. Knutson, R. Mathiasen, R. B. Smith, and R. K. Vickery, Jr commented constructively on the manuscript.

\section{References}

ALliENDE, M. C. AND HARPER, J. L. 1989. Demographic studies of a dioecious tree. I. Colonization, sex and age structure of a population of Salix cinerea. J. Ecol., 77, 1029-1047.

APARICIO, A. 1993. Sex-determining and floating translocation complexes in Viscum Sieber ex Boiss. (Viscaceae) in southern Spain. Some evolutionary and ecological comments. Bot. J. Linn. Soc., 111, 359-369.

APARiC1O, A., GALlego, M. J. AND VAZQuez, C. 1995. Reproductive biology of Viscum cruciatum in southern Spain. Int. J. Plant Sci., 156, 42-49.

BAKER, H. G. AND COX, P. A. 1984. Further thoughts on islands and dioecism. Ann. Mo. Bot. Gard., 71, 230-239.

BAKER, F. A., FRENCH, D. W. AND HUdLER, G. W. 1981. Development of Arceuthobium pusillum on black spruce. Forest Sci., 27, 203-205.

BARLOW, B. A. 1981. Viscum album in Japan: chromosomal translocations, maintenance of heterozygosity and the evolution of dioecy. Bot. Mag. Tokyo, 94, 21-34.

BARlow, B. A. AND Wiens, D. 1976. Translocation heterozygosity and sex ratio in Viscum fischeri. Heredity, 37, $265-272$

BARLOW, B. A., WIENS, D., WIENS, C. L. D., BUSBY, W. H. AND BRightON, C. 1978. Permanent translocation heterozygosity in Viscum album and V. cruciatum: sex association, balanced lethals, sex ratios. Heredity, 40, 33-38.

CAVALL1-SFORZA, L. L. AND BODMER, w. F. 1971. The Genetics of Human Populations. W. H. Freeman and Co., San Francisco.

CORRENS, C. 1928. Bestimmung, Vererbung und Verteilung des Geschlechtes bei den höhern Pflanzen. Handb. Vererbungsw., 2, 1-138.

COX, P. A. 1981. Niche partitioning between sexes of dioecious plants. Am. Nat., 117, 295-307.

CRAWFORD, R. M. M. AND BALFOUR, J. 1983. Female predominant sex ratios and physiological differentiation in Arctic willows. J. Ecol., 71, 149-160.

DAWSON, T. E. AND BL1SS, L. C. 1989. Patterns of water use and the tissue water relations in the dioecious shrub Salix arctica: the physiological basis for habitat partitioning between the sexes. Oecologia, 79, 332-343.

DAWSON, T. E. AND EHLERINGER, J. R. 1993. Genderspecific physiology, carbon isotope discrimination, and habitat distribution in boxelder, Acer negundo. Ecology, 74, 798-815.

DAWSON, T. E., EHLERINGER, J. R. AND MARSHALL, J. D. 1990. Sex ratio and reproductive variation in the mistletoe Phoradendron juniperinum (Viscaceae). Am. J. Bot., 77, 584-589.

FAL1NSK1, J. B. 1980. Vegetation dynamics and sex structure of the populations of pioneer dioecious woody plants. Vegetatio, 43, 23-38.

FiShER, R. A. 1958. The Genetical Theory of Natural Selection, 2nd edn. Dover Publications Inc., New York.

FORD, E. B. 1971. Ecological Genetics, 3rd edn. Chapman and Hall, London.

FREEMAN, D. C., KLIKOFF, L. G. AND HARPER, K. T. 1976. Differential resource utilization by the sexes of dioecious plants. Science, 193, 597-599.

Grant, v. 1975. Genetics of Flowering Plants. Columbia University Press, New York.

HAWksworth, F. G. 1961. Dwarf mistletoe of ponderosa pine in the Southwest. U. S. Dept Agric. Tech. Bull., 1246, 1-112.

HAWKSWORTH, F. G. AND SCHARPF, R. F. 1986. Spread of European mistletoe (Viscum album) in California, U.S.A. Eur. J. Plant Path., 16, 1-5.

HAWKSWORTH, F. G. AND W1ENS, D. 1972. The Biology and Classification of Dwarf Mistletoes (Arceuthobium). U. S. Department of Agriculture, Forest Service. Agriculture Handbook 401. U. S. Government. Printing Office, Washington, DC.

HAWKSWORTH, F. G. AND WiENS, D. 1996. Dwarf Mistletoes: Biology, Pathology, Systematics. U. S. Department of Agriculture, Forest Service. Agriculture Handbook. U. S. Government Printing Office, Washington, DC (in press).

KAY, Q. O. N. AND STEVENS, D. P. 1986. The frequency, distribution, and reproductive biology of dioecious species in the native flora of Britain and Ireland. Bot. J. Linn. Soc., 92, 39-64.

LAMONT, B. 1983. Mineral nutrition in mistletoes. In: Calder, M. and Bernhardt, P. (eds) The Biology of Mistletoes, pp. 185-204. Academic Press, Sydney.

LloYD, D. G. 1974. Theoretical sex ratios of dioecious and gynodioecious angiosperms. Heredity, 32, 11-34.

MEAGHER, T. R. 1988. Sex determination in plants. In: Lovett Doust, J. and Lovett Doust, L. (eds) Plant Reproductive Ecology, pp. 125-138. Oxford University Press, New York.

MECHELKE, F. 1976. Sex-correlated complex heterozygosity in Viscum album L. Naturwissenschaften, 63, 390.

MINOZ, S., LIMA, H., PEREZ, M. AND RODRIGUEZ, O. L. 1982. Use of the peroxidase enzyme system for the identification of sex in Carica papaya. Ciec. Tec. Agric. Citricios Otros Frutales, 5, 39-48.

MU1R, J. A. 1968. Biology of Dwarf Mistletoe (Arceutho- 
bium americanum) in Alberta. Internal Report A15, Canada Department of Fisheries and Forestry, pp. 1-29. Calgary, Alta.

MULCAHY, D. L., WEEDEN, N. F., KESSELI, R. AND CARROLL, s. B. 1992. DNA probes for the Y-chromosome of Silene latifolia, a dioecious angiosperm. Sex. Plant Repro., 5, $86-88$.

NICKRENT, D. L. 1986. Genetic polymorphism in the morphologically reduced dwarf mistletoes (Arceuthobium Viscaceae): an electrophoretic study. Am. J. Bot., 73, 1492-1502.

NICKRENT, D. L. AND BUTLER, T. L. 1990. Allozymic relationships of Arceuthobium campylopodum and allies in California. Biochem. Syst. Ecol., 18, 253-256.

NICKRENT, D. L. AND STELL, A. L. 1990. Biochemical systematics of the Arceuthobium campylopodum complex (dwarf mistletoes, Viscaceae). II. Electrophoretic evidence for genetic differentiation in two host races of hemlock dwarf mistletoe (Arceuthobium tsugense). Biochem. Syst. Ecol., 18, 267-280.

NIXON, K. C. AND TODZIA, C. A. 1985. Within-population, within-host species, and within-host tree sex ratios in mistletoe (Phoradendron tomentosum) in central Texas. Am. Midl. Nat., 114, 304-312.

SCHARPF, R. F. AND PARMETER, J. R. 1966. Determining the age of dwarf mistletoe infections in red fir. $U$. S. Forest Service Research Note, PSW, Berkeley, CA, 105, 1-5.

SCHARPF, R. F. AND PARMETER, J. R. 1982. Population dynamics of dwarf mistletoe on young true firs in the central Sierra Nevada, California. Pacific Southwest Forest and Range Experimental Station, U. S. Department of Agriculture, Berkeley, CA, Forest Service, Research Paper, 161, 1-9.

SCHINK, M. AND MECHELKE, F. 1989. Sex-correlated differences in the protein pattern of Viscum album $\mathrm{L}$. revealed by two dimensional gel electrophoresis. Naturwissenschaften, 76, 29-30.

SCHNABEL, A. AND HAMRICK, J. L. 1990. Nonrandom association between sex and 6-phosphogluconate dehydrogenase isozyme genotypes in Gleditsia triacanthos L. $J$. Hered., 81, 230-233.

SHAW, C. G., III. 1982. Development of dwarf mistletoe infections on western hemlock regeneration in southeast Alaska. Can. J. Forest Res., 12, 482-488.

SHAW, C. G., III. AND HENNON, P. E. 1991. Spread, intensification, and upward advance of dwarf mistletoe in thinned, young stands of western hemlock in southeast Alaska. Plant Dis., 75, 363-367.

SHOWLER, K. 1974. Raising mistletoe (Viscum album) from seed. J. R. Hort. Soc., 99, 30-37.
SMITH, R. B. 1969. Assessing dwarf mistletoe on western hemlock. Forest Sci., 15, 277-285.

SMITH, R. B. 1971. Development of dwarf mistletoe (Arceuthobium) infections on western hemlock, shore pine, and western larch. Can. J. Forest Res., 1, 35-42.

Steel, R. G. D. AND TORRIE, J. H. 1980. Principles and Procedures of Statistics, 2nd edn. McGraw-Hill, New York.

SUGANUMA, H. AND IWASAKI, F. 1983. Sex identification of dioecious plants by the isozyme method. Date (Phoenix dactylifera L.). Jap. J. Trop. Agr., 27, 75-78.

WESTERGAARD, M. 1958. The mechanism of sex determination in dioecious flowering plants. Adv. Genet., 9, 217-281.

WICKER, E. F. 1967. Seed destiny as a klendusic factor of infection and its impact upon propagation of Arceuthobium spp. Phytopathology, 57, 1164-1168.

wIENs, D. 1968. Chromosomal and flowering characteristics in dwarf mistletoes (Arceuthobium). Am. J. Bot., $\mathbf{5 5}, 325-334$

WIENS, D. 1984. Ovule survivorship, brood size, life history, breeding systems, and reproductive success in plants. Oecologia, 64, 47-53.

WIENS, D. AND BARLOW, B. A. 1973. Unusual translocation heterozygosity in an East African mistletoe (Viscum fischeri). Nature, 243, 93-94.

WIENS, D. AND BARLOW, B. A. 1975. Permanent translocation heterozygosity and sex determination in East African mistletoes. Science, 187, 1208-1209.

WIENS, D. AND BARLOW, B. A. 1979. Translocation heterozygosity and the origin of dioecy in Viscum. Heredity, 42, 201-222.

wiEns, D. AND SHAw, C. G., III. 1994. Arceuthobium hawksworthii (Viscaceae), a new species from Belize. J. Idaho Acad. Sci., 30, 25-32.

WIENS, D., CAlVin, C. L., Wilson, C. A., DAVERn, C. I., FRANK, D. AND SEAVEY, S. R. 1987. Reproductive success, spontaneous embryo abortion, and genetic load in flowering plants. Oecologia, 71, 501-509.

willson, M. F. 1983. Plant Reproductive Ecology. John Wiley and Sons, New York.

WULFF, K. 1987. Genetic analysis of ecologically relevant morphological variability in Plantago lanceolata L. 2. Localization and organization of quantitative trait loci. Theor. Appl. Genet., 73, 903-914.

ZARZYCKI, K. AND RYCHLEWSKI, J. 1972. Sex ratios in Polish natural populations and in seedling samples of Rumex acetosa L. and R. thyrsiflorus Fing. Acta Biol. Cracoviensia, Ser. Bot., 15, 135-151. 